\title{
広振動数範囲を対象とした水平振動感覚の評価に関する検討 SENSORY ASSESSMENT OF HORIZONTAL VIBRATION OVER A WIDE FREQUENCY RANGE
}

\author{
石川孝重*, 野田 千津子** \\ Takashige ISHIKAWA and Chizuko NODA
}

\begin{abstract}
In this study the sensory experiment on sense of horizontal vibration was done. It was over a wide frequency range assuming the vibration in low-rise and high-rise buildings. This paper investigates the characteristics of five scales; degree of discomfort and magnitude, sensory limit assessment, uneasy feelings and expression with adjectives. Every scale has the opposite slides in a low and a high frequency range. More physical assessment has a clearer relation with a single physical element. More subjective assessment varies more widely and has a stronger effect of acceleration. The comparative result between the scales finds the relative differences of them. Because the highest scale differs on a vibration range, it is needed to grasp such sensory characteristics to reduce inhabitants' complaints.
\end{abstract}

Keywords: Horizontal vibration, Sensory assessment, Scale, Psychometric method, Semantic Differential method, Habi tability 水平振動, 感覚評価, 評価尺度, 心理学的測定法, S D法, 居住性

\section{1.はじめに}

居住性評価の規範として水平振動に対寸る感覚に着目した既往研 究のほとんどは，風や地震などで高層・超高層住宅に生じる長周期 水平振動を想定したもの"゙であった。この範囲の振動を対象とした 学会指針 ${ }^{2)}$ もここうら既往研究の成果をふまえたものである。し かし近年では 3 階建ての戸建て住宅が增えるにつれ，これらの低首 建物で交通や工事などによって生じる高振動数の水平振動が居住性 に支障をきたす事例も発生しておうゔ，このような高振動数範囲を 対象とした研究も中田ら”などにいくつかみられる。音響学会には これらの振動数範囲を包含した三輪ら ${ }^{5)}$ の研究などがあるが，建物 の居住性を観点とした既往研究では対象振動数範囲が限定されてお り，高層から低層建物までを想定した厇い振動数範囲を対象に統括 した条件で実験を行ったものはない。これらの既往研究の結果を比 較した ${ }^{6)}$ とろ実験時の総合的な環境条件や振動の入力方法, アン ケート方法など, 周辺的な条件の違いによって水平振動の知覚に大 きな違いが生じることとがわかっている。そのため, 異なる振動数 範囲を対象に数多く蓄積された既往の成果を，同じ位置づけで比較 することが難しい。そこで, 広振動数範囲を対象とした水平振動感 覚を知るためには，1つの統一した実験条件で行った結果の提示が 求められる。

筆者らはこれまでにも，0.1Hz〜1.6Hzまでを中心とした低振動数
範囲の水平振動感覚に関する実駼結果を報告してきた ${ }^{199}$ が, 本研 究では上記の実状をふまえ，実験範囲を0.1〜40Hzまでとした。 0.1 〜 $1 \mathrm{~Hz}$ 程度までの超高層住宅における長周期の振動, 3Hz前後を中心 とした低層住宅の交通振動, さらに高振動数の振動が予想される機 械設備などによる振動を想定している。ここではこれまでの研究の 流れをふまえ,これらの振動について水平振動の観点からとらえる ものとし, 広振動数範囲の水平振動に対する感覚を唡討する。

一方, 先の学会指針 ${ }^{1}$ をはじめとして, 建物の振動に対する居住 性に関しては，振動を感じないことを前提とした評価が従来の主流 となっており，知覚閥の把握に関してはこれまでにも多くの蓄積が ある。しかしこのように高層化，多様化が進む将来の居住環境では， 振動を感じないレベル，すなわち知覚䦨以下におさえることが一層 難しくなることは否めない。そこで今後は知覚闌以下に振動をおさ えるだけでなく，ときに知覚闌を越えるレベルとなる振動を居住者 の感覚にそった許容範囲におさえる評価を考える必要がある。その ためには，知覚しうる振動に対して生じる感覚の詳細な把握が重要 になる。そこで本論文では，振動の大きさ，振動に対する不快感や 不安感などの心理的な判断を含む評価尺度に着目し, 従来の評価の 規範である知覚との対応関係を明らかにする。それに基づいて各評 価尺度の特性を明らかにし，相互に位置づけることが目的である。 なお，この一部は既に文献间において速報している。
*日本女子大学住居学科 教授·工博

** 小山工業高等尃門学校建築学科 助手・修士(家政学)
Prof., Dept. of Housing, Japan Women's Univ., Dr. Eng.

Research Assoc., Dept. of Architecture, Oyama National College of Technology, M. H. E. 


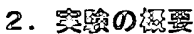

実唋では振動台上に $3 \mathrm{~m}$ 四方, 高さ $3 \mathrm{~m}$ の鋼材製の居室を設置し た。図1に示すようにこの居室にはサッシ空があるが，今回の実験 では銅材製のふたをして外部と遮断し，視覚的な影響がないように 配虑した。このなかで椅子に腰挂けた 43 名の被験者(女性，18〜24 歲)に対して, 左右の水平方向に定常的な正弦振動を与えた。動電 型の加振装置を用いているため振動発生器からの機械强音はきわめ て小さい。また居空の壁は鈴板の間に $10 \mathrm{~cm}$ 程度のグラスウールを遮 音材として充填し，外部からの怿音にも配慮している。この壁体は 外部の騒音を $15 \mathrm{~dB}$ 低減させる効果をもつ。さらに実耠中は一定の音 鼠で音楽を流した。
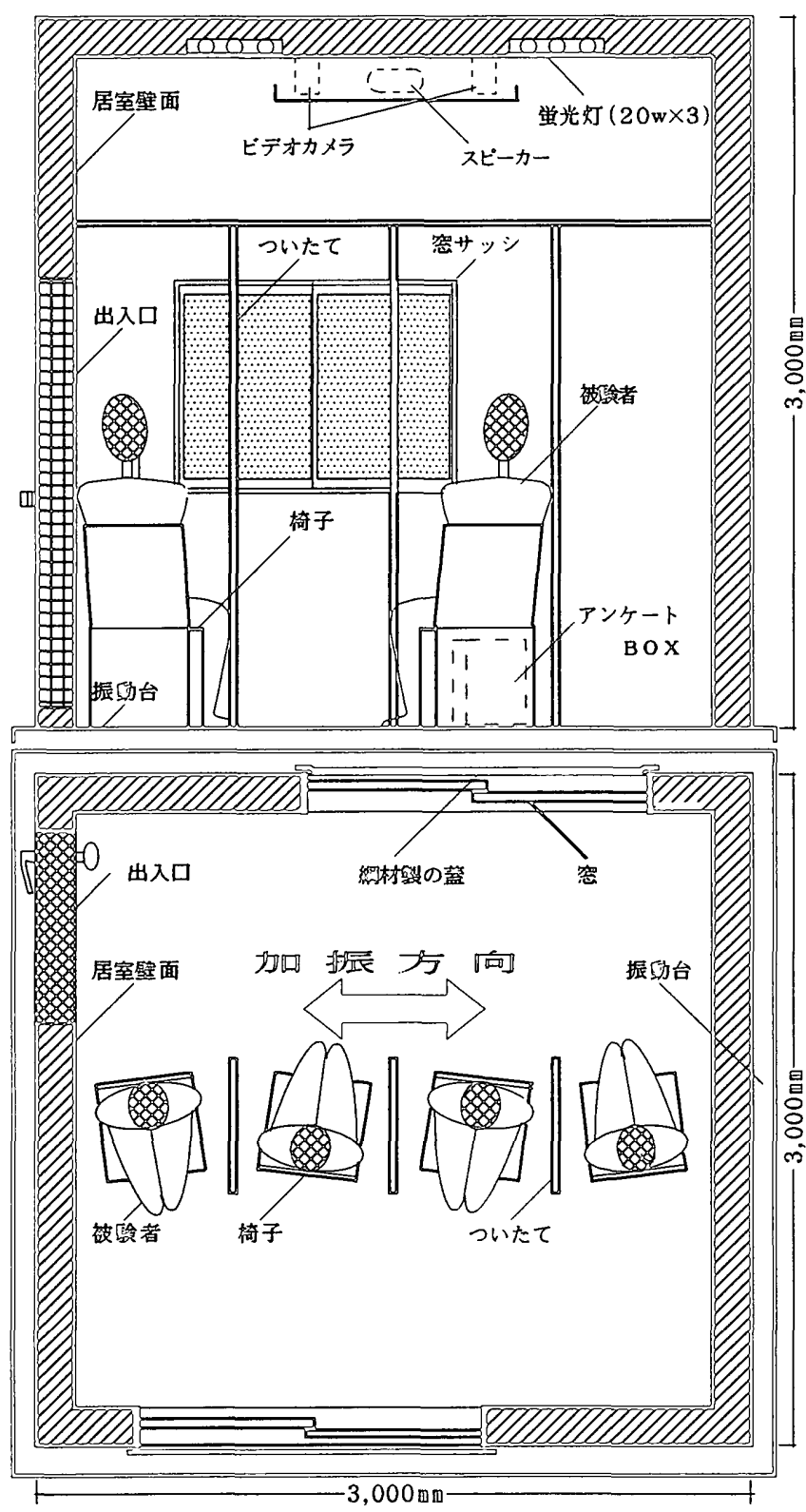

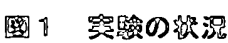

入力振動は振動数0. 1 40Hz, 加速度最大値1.6 400gal, 変位最 大值 $0.000025 \sim 10 \mathrm{~cm}$ (以降, 単に加速度, 変位とする）の䈇囲で49 㮩穎の振動を設定した。これに無入力を加えた合計50種頑の振動を
被験者に与えた。これらの振動は実験中にひずみゲージ式加速度計 とオシログラフィックレコーダを用いて実測し，再現性をその都度 確認した。この方法で振動台上や椅子上などの加速度を実測した結 果, 感覚に対して支配的であった椅子上の振動の実測値を振動換算 図上に○でプロットしたものが図 2 であり，波形の一例を図 3 に表 す。換算図の○付近の交点は入力の目標值であり, 振動台上の加速 度とほぼ一致する。

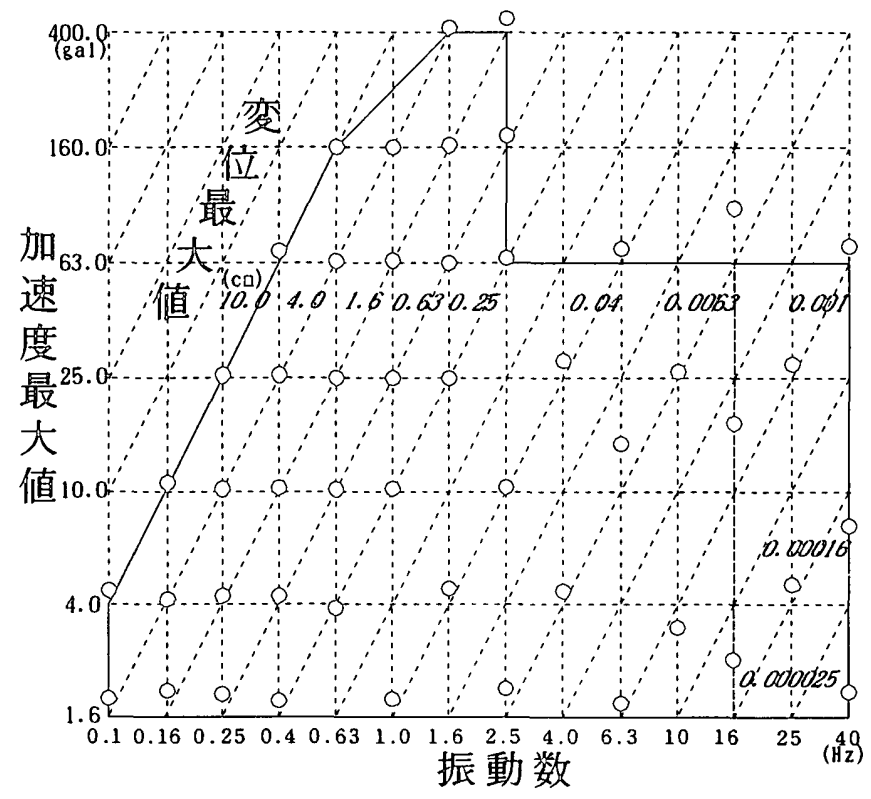

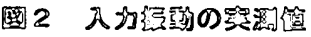

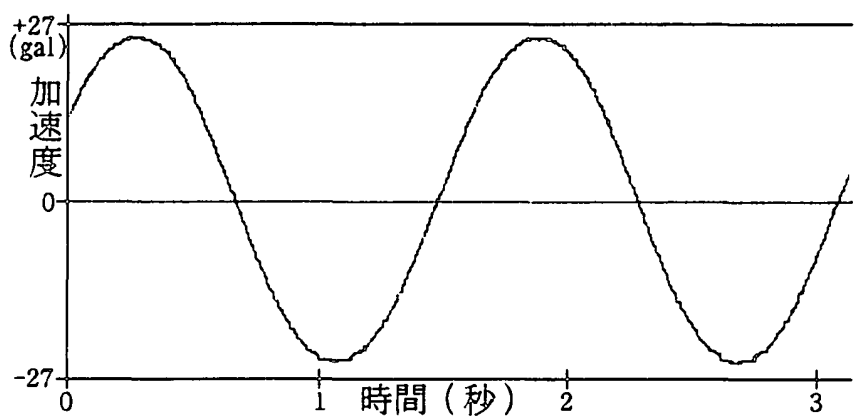

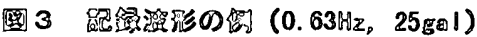

図 4はアンケート用紙のなかの本論文でとりあげた部分である。 設定した評価尺度を表 1 に示す。この用紙を用いて, $0.63 \mathrm{~Hz}, 25 \mathrm{gal}$ ， $1.6 \mathrm{~cm}$ の振動を基準とした各振㽖との一対比㪟のアンケートを行っ た。被医者は基準とする振動を 30 秒間感じた後,アンケート用紙の 所定の貎問に回答する。さらに，約10秒間振動を停止した後，入力 筑囲のある 1 種頻の振動を感じながら，実験者の指示に従って残り の蜇問に順次回答する。この手続きを全50種頑の振動に対して繰り 返して行い，1 単位の実鍳を終了した。比洨对象となる各振動の入 カ順序はランダムに設定した。

CCDカメラと内部マイクを用いて居室内部の被験者の状況を外部 から常にモニタリングしながら, 比較対象の各振動の入力時間を 180 秒程度で調整した。その他の指示なども寸べてマイクを通じて外か 


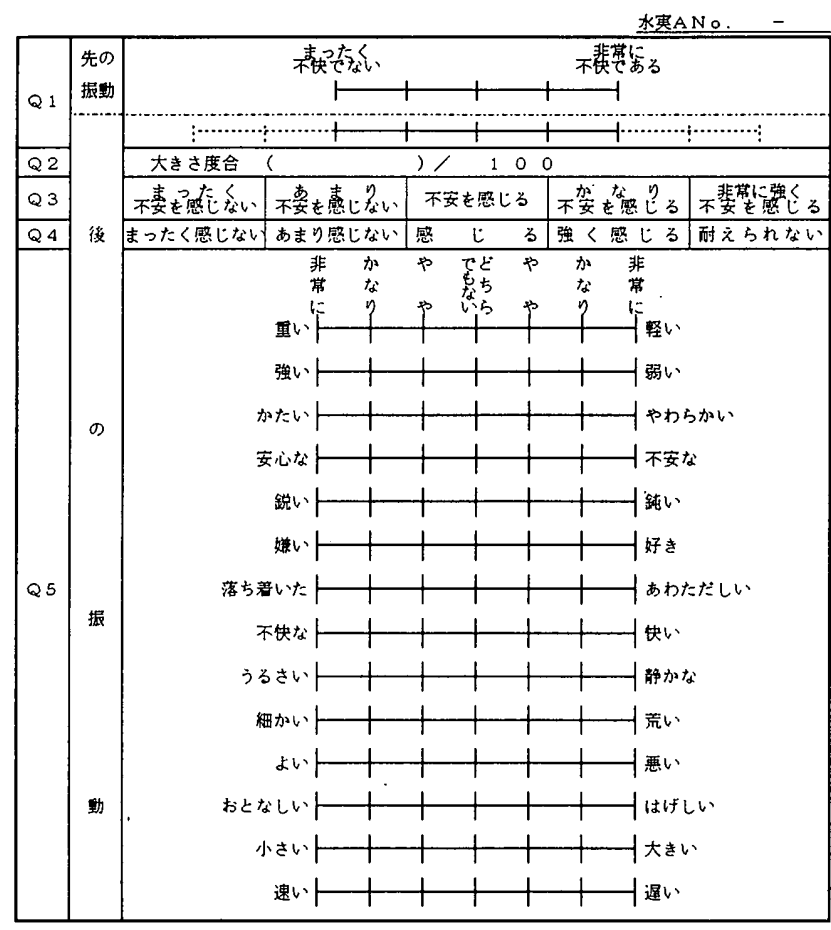

图 4 アンケート用紲

\section{表 1 設定した評画尺度}

\begin{tabular}{|c|c|c|}
\hline 名称 & 笋価手法 & 評価方法・意味つけ \\
\hline 不快度合 & $\begin{array}{l}\text { 数值尺度法 } \\
\text { 相対許価 }\end{array}$ & 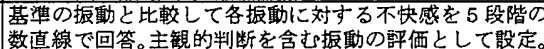 \\
\hline 大封度合 & 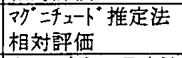 & 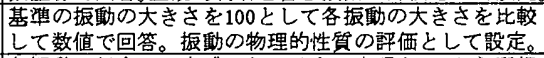 \\
\hline 不安感 & $\begin{array}{l}\text { カテゴリー尺度法 } \\
\text { 絶対評価 }\end{array}$ & $\begin{array}{l}\text { 各振動に対する不安感にあてはまる表現を5つから選択。 } \\
\text { 日常環境での諲価に近い表現として般定。 }\end{array}$ \\
\hline 限界滆価 & $\begin{array}{l}\text { カテコリー尺度法 } \\
\text { 絶対訲価 }\end{array}$ & $\begin{array}{l}\text { 各振動を感じた程度にあてはまる贵現を5つから選択。 } \\
\text { 知賞限界から竍容限界を含む感党限界の表現として殷定 }\end{array}$ \\
\hline 形容詞に & $\begin{array}{l}\mathrm{SD} \text { 法 } \\
\text { 絶対㰻価 }\end{array}$ & 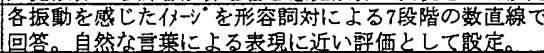 \\
\hline
\end{tabular}

ら行っており，実験中に実験者が居室内に入ることはない。

\section{3. 水平振動感覚を表す 4 つの評自尺度の特性}

図4のアンケート用紙に示したうち心理学的測定法"1) 用いた 4 つの評価尺度と物理成分とのかかわりに着目し, 各評価尺度の特性 について分析する。

\section{1 感営限界の評面}

図 5 は各振動に対するそれぞれの表現の回答率を直線補間して求 めた，限界評価の回答率曲線である。図中の実線は「まったく感じ ない」, 点線は「強く感じる」と「耐えられない」と回答した人の 回答率を示す。この実験範囲では「耐えられない!と回答した人が 少なかった。実験では振動の発生を予知している上, 最終的には安 全であることの安心感などもあり，実環境とは評価に違いがあるこ とが予測できる。そのためここでは「耐えられないりと「強く感じ る」の回答を統合して扱うこととした。

「まったく感じない」の回答率曲線は本実験における知覚曲線と して評価できる。各曲線は $2.5 \mathrm{~Hz}$ 付近を境に傾きが逆となり，下に 凸となることが特徴的である。文献”でも同じような位置に傾きが 逆になる点があり，水平振動の知覚は振動数範囲によって特性が異 なることがわかる。全体として加速度が大きいほど回答率は低いが， 「まったく感じない」にあてはまる振動の範囲が狭く曲線の間隔が

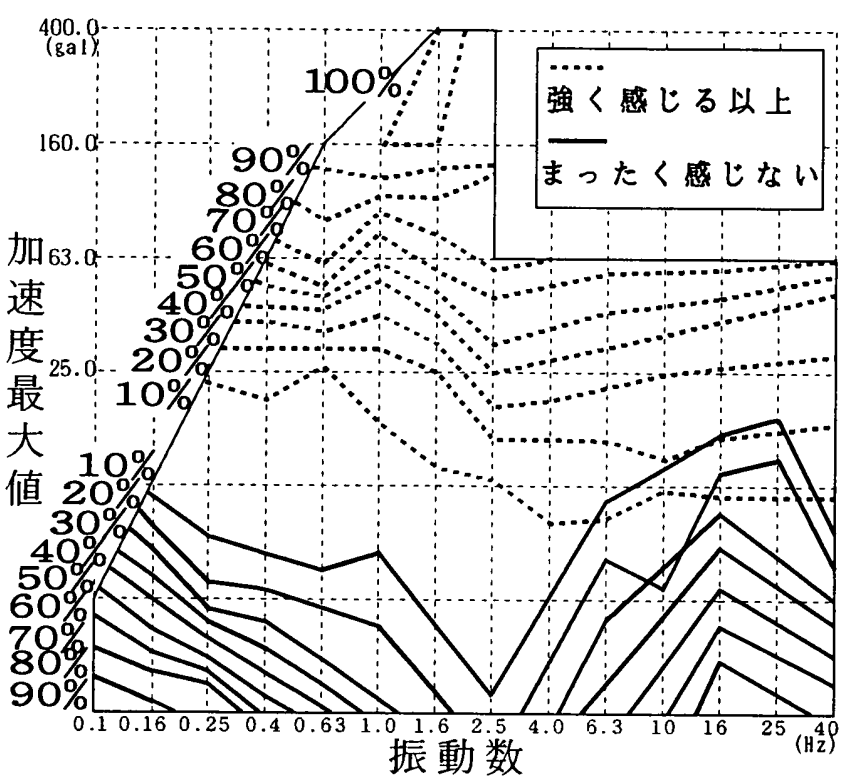

図 5 限界評任の回答率曲線

ほぼ均一であり, 知覚は物理量の変動に対して鋭敏な反応であると 推察できる。この傾向は特に低振動数範囲で顕著である。

一方「強く感じる」以上の曲線は全体的に加速度に沿う傾向が強 い。加速度が大きいほど回答率が高く, 振動を感じる強さ, 振動に 対する許容限界の表現は加速度に依存する。「まったく感じない」 と同様に, 低振動数範囲の方が物理量の変動に対して感覚的に鋭敏 な反応を示す。一方高振動数範囲では低い回答率の曲線が加速度が 低い範囲に広がり，「まったく感じない」の回答率曲線と重なる範 囲もある。高振動数の振動に対する被験者のとらえ方にはばらつき が大きく，個人差が生じやすいことがわかる。

\section{2 大きさ度合の評面}

図6では, 各振動の大きさ度合の平均值を直線補間した等評価曲 線を常用対数で等間隔に表現した。各曲線は限界評価と同様, $2.5 \mathrm{~Hz}$ 付近を境に傾きが逆になる。25gal程度までは曲線はほぼ等間隔で

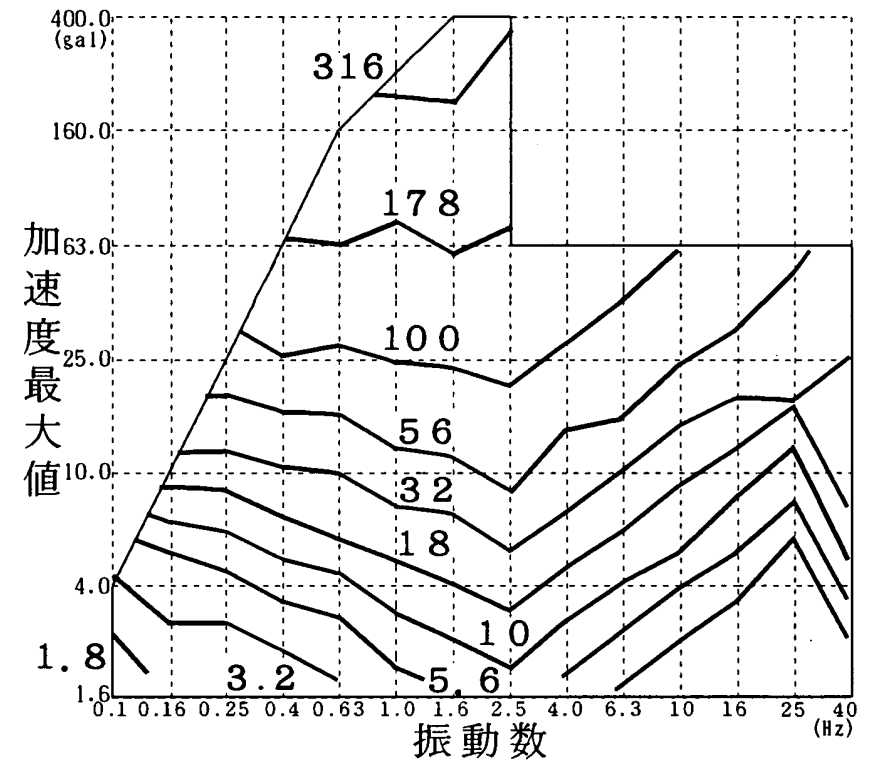

图 6 大きさ度合の等評而曲線 
ある一方, それ以上の加速度では曲線の間隔が徐々に広がることが 特徴的である。振動の大きさの評価では, 物理量の変動に対する増 加率が加速度の大きさによって変化する。

低振勁数筑囲では加速度が小さいほど曲線が右下がりとなり，加 速度が小さい振動の大きさの評価は振動の知覚と関保することが推 察できる。一方振動を明らかに感じる10gal以上の筑囲では, 曲線 は加速度に沿う傾向が強くなり，大きさの評価は加速度に依存寸る。 また2. $5 \mathrm{~Hz}$ 以上では約 $45^{\circ}$ に右上がりの曲線がほぼ等間隔にあり， 高振動数筑囲の大きさの評価は速度とのかかわりが強い。

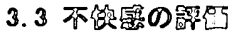

不快度合では「まったく不快でない」を1，「非常に不快であ る」を 5 ，両者の間の各段階を $2,3 ， 4$ として評価した。図 7 で は，各振勁と基準とする振動に対する不快度合の差をとった相対的 な不快度合を表した。各等評価曲線の一は基準とする振動より不快 感が小さいこと，十はより大きいことを表す。

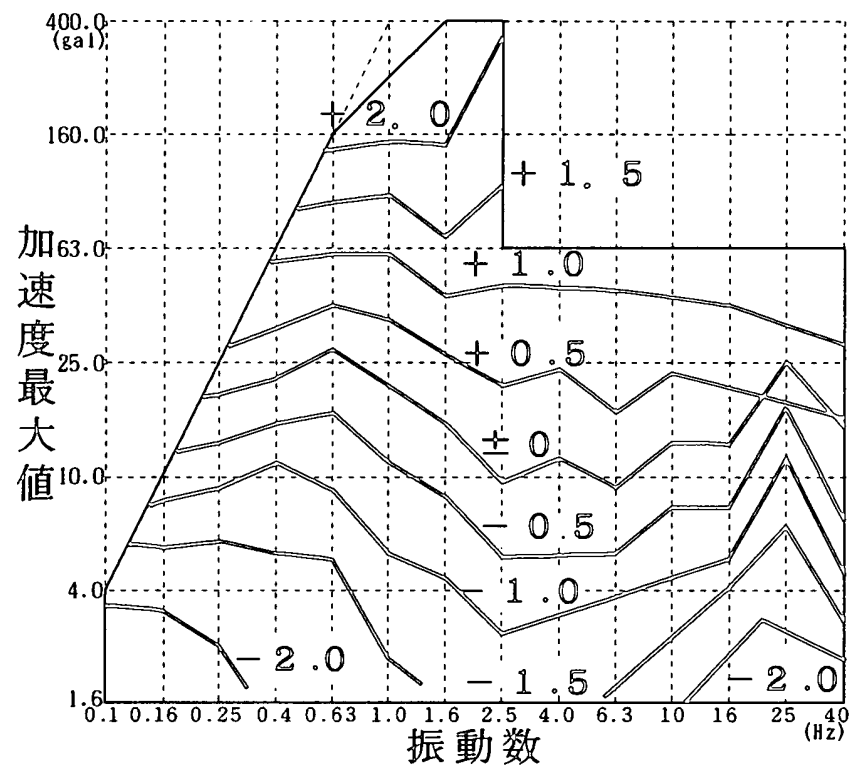

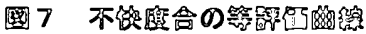

他の尺度と同じように $2.5 \mathrm{~Hz}$ 付近，さらに変位が大きい筑囲で曲 線の傾きが逆になることが不快度合の特徴である。限界評価，大き さ度合と比べて各曲線は複雑に折れ曲がり，振動に対する不快感の 評価は振勁の筑囲によって影響する物理成分が異なる上，それ以外 の要因にも影響を受けてばらつくことがわかる。高振動数節囲では 曲線の折れ曲がり方がより複雑であり，より多様な要因に影響を受 けてばらつきが大きくなっているものと推察できる。

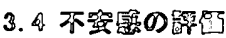

図8は不安感の回答率曲線である。実線は「まったく不安を感じ ない」，点線は「かなり不安を感じる」と「非常に強く不安を感じ る」と回答した人の回答率曲線を示す。

回答率曲線の笻囲が広いことからもわかるように，「まったく不 安を感じない」の回答は全振動に対してみられ，振動を感じること や不快感が不安感に直接通じないことがわかる。他の評価尺度と同 じように2.5Hz付近を境に曲線の傾きが逆になり，全体的には加速 度が大きくなるほど回答率は低くなる。

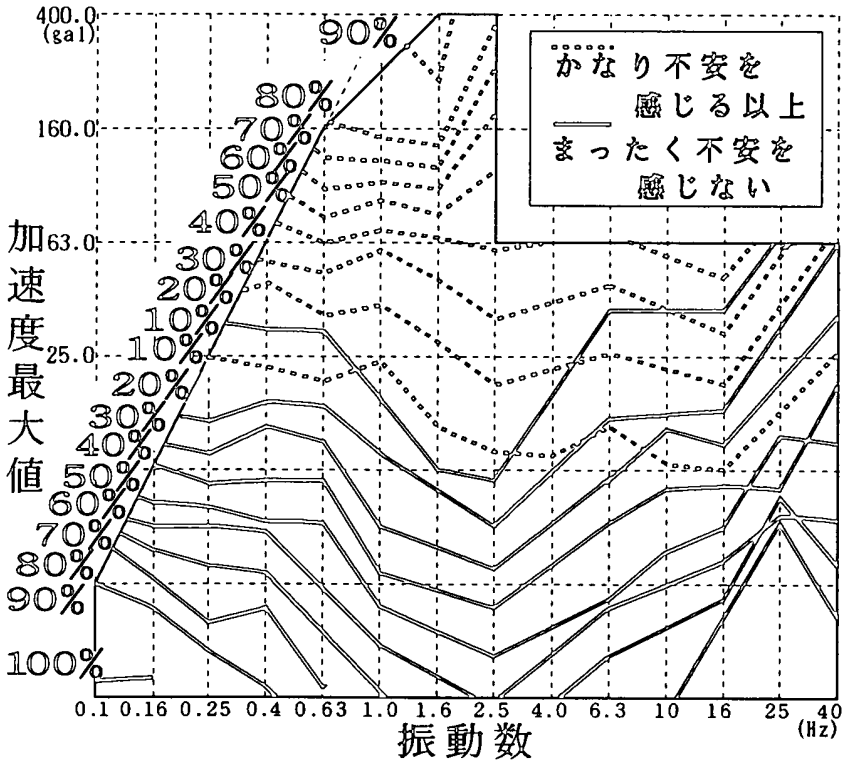

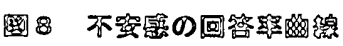

一方かなり不安を感じる」以上の曲線は，全体的には加速度軸に 沿う傾向が強い。「強く感じる」以上の曲線と同様に, 高加速度筑囲 の振動に対する不安感の評価は加速度に依存する傾向が強いことが わかる。

不安感では特に実験時と実環境とで評価が異なることが予想され， 実験時の評価にはこの評価尺度に対する被験者個々のとらえ方の遥 いが影響することが，被験者に対する実臨後のヒヤリングからわか っている。各曲線はもっとも複雑に折れ曲がり，「まったく不安を 感じない」と「かなり不安を感じる」以上の回答率曲線が重なる箅 囲も広い。振動に対する不安感の評価は振動の物理的変動に対寸る 反応だけでなく、主観的な心理判断が含まれる程度が強いために被 験者による個人差やばらつきが大きいものと推察できる。

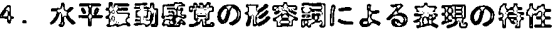

これら 4 つの評価尺度は, 実験者が設定したとらえ方に基ついて 評価される。そこで被鈳者のより自由な表現を知るためにS D法に 基づく評価を試みた。図4に示す形容詞対は，これまでの結果”を 鑑みて水平振動感覚とかかわりが強い言葉を中心に選択し, SD法 の基本尺度(2) と呼ばれるものを含めた。

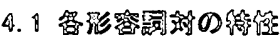

各被験者がそれぞれの振動に対して14組の形容詞対に与えた評点 を 1 サンプルとし，この結果に対して主成分分析を行った。固有值 1.0以上の主成分を採用した結果，敖 2 に示寸固有值，寄与率をも つ第 3 主成分までを抽出した。各主成分を縦横の軸にとり，これら の主成分に対する各形容詞対の負荷量を示したものが図 9 である。

第 1 主成分に対しては一側に否定的な，十側に肯定的な意味あい の形容詞が集まる。負荷量が高い形容詞対ほど振動を否定的, 肯定

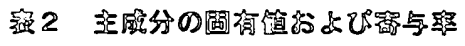

\begin{tabular}{|c|c|c|c|}
\hline & 固有值 & 需与率 $(\%)$ & 䔬程需与率 $(\%)$ \\
\hline 第 1 主成分 & 8.08 & 7.7 & 57.7 \\
\hline 第 2 主成分 & 2.05 & 4.6 & 72.3 \\
\hline 第 3 主成分 & 1.04 & 7.4 & 79.7 \\
\hline
\end{tabular}




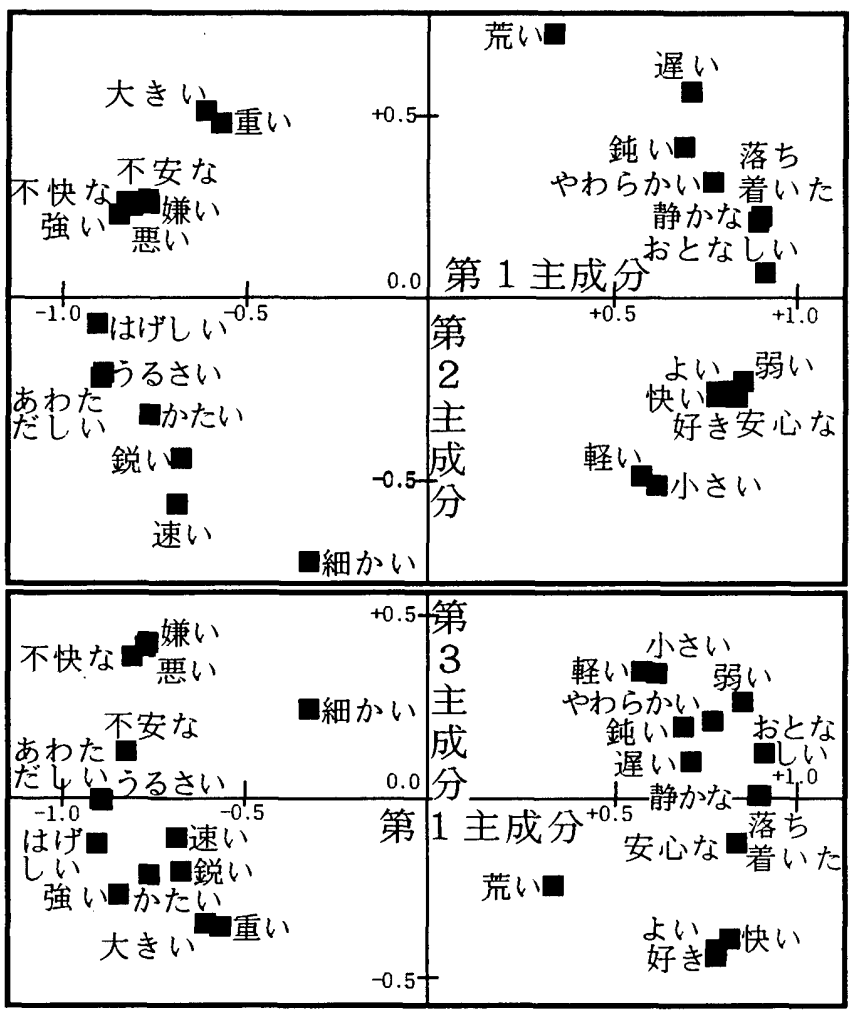

图 9 各主成分に対する形容詞対の負荷量

的に表現する意味あいが強く，振動が感覚に働きかける強さを表す 主成分と考えられる。これはS D法による既往研究で一般的に抽出 される力量性に対応寸るものであろう。一方第 2 主成分は「荒い/ 細かい」の負荷量がもっとも高く, 負荷量が高い形容詞ほど振動そ のものの性質を表現する傾向が強い。これは一般的な活動性に対応 するものと考えられる。

さらに第 3 主成分は約 $45^{\circ}$ の角度で 2 つの軸が直交した性質をも つ。1つは「好き/嫌い」など振動に対する好悪の評価を表才評価 性，もう1つは変位の大きさと対応した「小さい/大きい」などの 形容詞対である。既往の結果でも「小さい/大きい」は表現する対 象によって特徴的な変動を示すことが指摘されており ${ }^{122}$, 水平振動 感覚の表現でも他の形容詞対と異なる特徴的な変動を示す。

この結果はこれまでに行った実験”とも等しく, 水平振動感覚を 表現する言葉の特性として確度が高い結果であると考えられる。

\section{2 評面性に基すく形容詞対の表現の領域}

このような 3 つの特性をもつ形容詞対と物理成分との関倸を知る ためにそれぞれの表現に対応する水平振動の領域化を試みた。解析 にはspssのクラスター分析を用い，説明変数を各サンプルの第 1 〜 第 3 主成分得点として全2150サンプルをクラスター化した。クラス ター間の距離はユークリッド距離, 融合後の距離の計算方法は最近 重心ソート法とした。ここではこのクラスターの性質のなかで, 第 3 主成分得点に対応して変動する評価性に着目する。

各被験者の表現に基づいた評価曲線を設定するために，以下のよ うな手順で解析を行った。まず各クラスターに含まれるサンブルを 被験者ごとに集計し, 個々の被験者における表現に対応した振動の 領域を知る。これらのクラスターに含まれるサンプルの主成分得点 の分布から，個々の被験者が肯定的，否定的，中立すなわちどちら
でもない状態として評価する水平振動の領域を分化した。この結果 に基づき，各振動に対して肯定的，否定的，中立に評価した人数を 集計して，それぞれの人数に対応する肯定・中立・否定評価の領域 を求めた。図10では全被験者数の約 $1 / 3$ である12人以上の各評価 の領域を重ねあわせた，形容詞による表現の評価領域を表す。

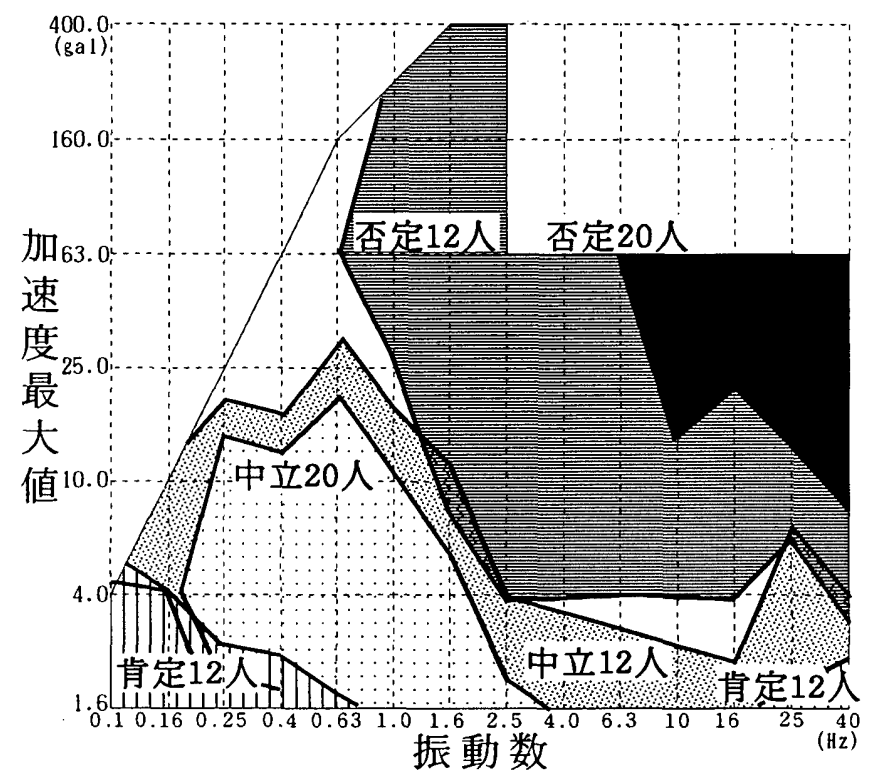

因10形容詞による表現の詳任領域

肯定的に評価される領域では人数がさほど多くないが，これは感 じない振動を肯定的にとらえるか，中立ととらえるかが人によって 異なることによる。そのため加速度が小さい範囲の振動を中立に評 価する人数も多く，肯定評価の領域と中立評価の領域が重なる。

各評価の領域は2.5Hzを境に変化する。低振動数範囲では加速度

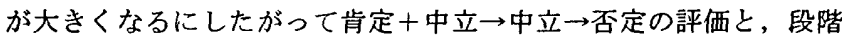
的に領域が分かれる。このなかで変位が大きい範囲にどの評価にも あてはまらない領域があるが，これは変位が大きい範囲を否定的に 評価する人が数名いる以外，この範囲の振動に対する評価がばらつ くことによる。

一方高振動数範囲では，否定的に評価される領域が加速度がかな り小さい範囲まで広がることが特徽的である。形容詞による表現で は，他の評価尺度にはみられない振動数に対応した振動の性質を表 現する活動性が存在する。高振動数範囲の振動に対してはこの活動 性による振動数が高いという表現が卓越し，ほとんどの振動が否定 的に評価される 1 つのクラスターとして領域化されるためである。

\section{5. 水平振動に対する評面特性の相互比较}

上述の考察をふまえ，図11では各評価尺度の特性を相互に比較し やすくするために振動数ごとに評価値を重吕わせてみた。横軸に 加速度, 縦軸に評価値をとって表現した。評価值のレベルは図に示 したように設定し，各評価尺度を相対的に位置づけてみた。その際 にはそれぞれの手法に添った意味づけが適当であると考え，評価手 法に対する心理学な認識を考慮して各評価尺度の扱い方を次のよう にした。大きさ度合と不快度合では平均値，限界評価と不安感では 各表現に対する回答率から評価值を設定した。この際には過半数と 


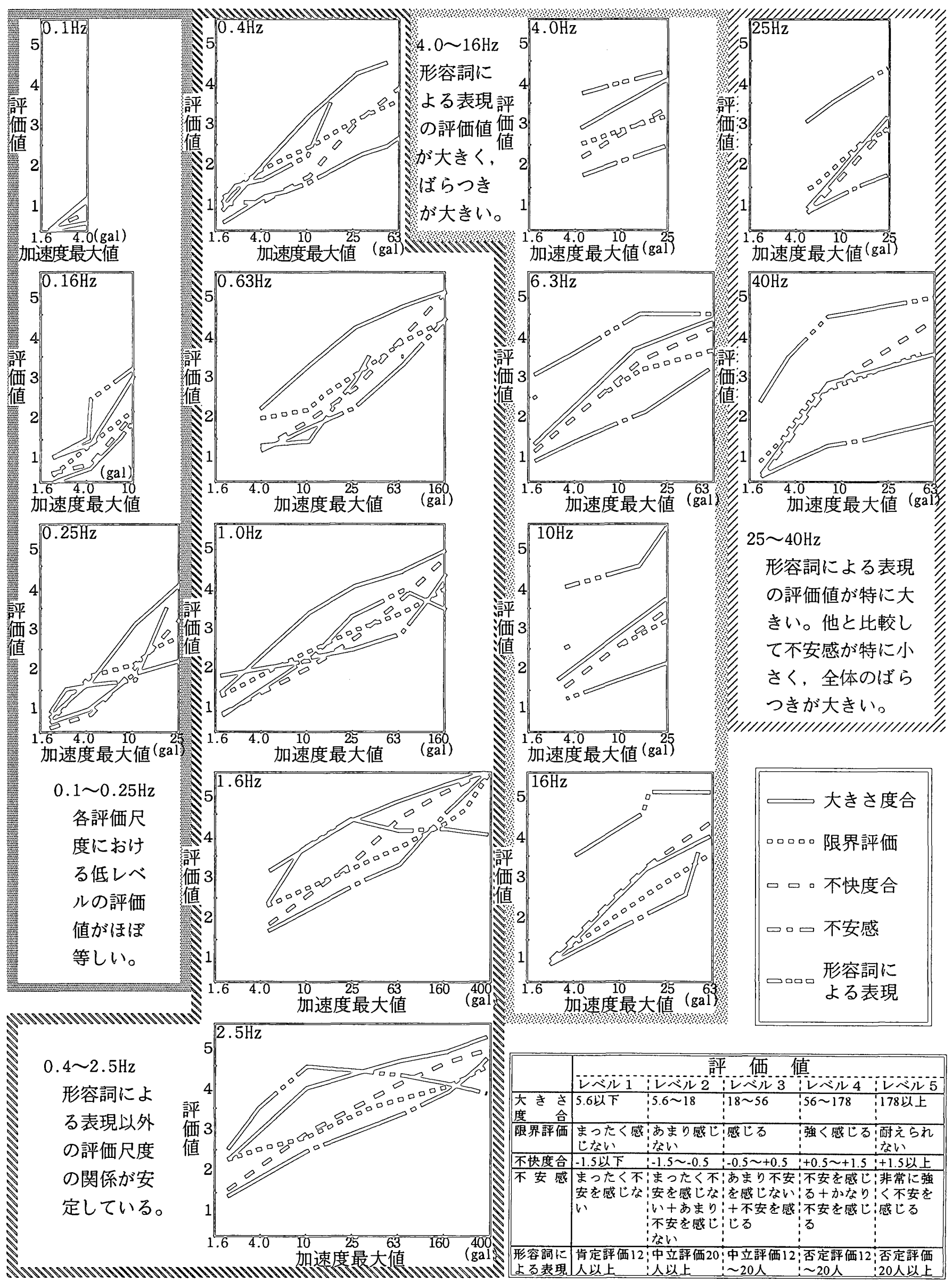

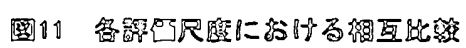


いう代表值としての意味をもたせるため，50\%以上の回答を得た振 動の範囲に着目したが, 不安感では回答のばらつきが特に大きく, 1 つの表現に限定すると $50 \%$ 以上の回答を得た振動がない場合もあ

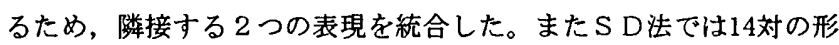
容詞を 1 つの表現としてとらえるため, 前述の多変量解析の結果か ら評価値を求めた。各評価尺度の違いから振動数範囲を 4 つに区切 ることができる。

振動数がもっとも低い0.1〜0.25Hzでは各評価尺度の低レベルの 評価值がほぼ等しく，知覚と関倸した評価であることがわかる。一 方加速度が比較的大きい範囲では評価尺度によるばらつきが大きい。 振動数, 加速度が全体的に低く振動の刺激量が小さいため, 各評価 尺度のばらつきが大きくなっているものと推察できる。

次に低い振動数範囲である0.4〜2.5Hzでは，全評価尺度の関保は 安定した傾向にある。最大と最小の大きさ度合と不安感が不快度合 と限界評価をはさむようなかたちとなる。不快度合と限界評価の大 小関係は10〜25gal程度の範囲で入れ替わる。

振動数が若干高い4. $0 \sim 16 \mathrm{~Hz}$ では，形容詞による表現の評価值が 大きく，全評価尺度のばらつきが大きくなることが特徴的である。 そのなかで，大きさ度合と不快度合の増加率がほぼ対応している。

さらに振動数が高い25 40Hzでは，形容詞による表現の評価值が 特に大きい。他の評価尺度のなかでは不安感以外がほぼ対応してお り，不安感は他と比較して特に小さく，評価尺度全体のばらつきが より大きくなる。

これらから各評価尺度の特街を以下のように組めることができる。 大きさ度合は加速度が低いほど評価值の增加が大きく, 加速度が 大きくなるにしたがって評価值の増加が徐々に小さくなる。不安感 はそれと逆に加速度がある程度小さい範囲では評価值の増加は鈍い が，加速度が大きくなるにしたがって評価值の增加も大きくなる。 特に63ga1以上で不安を強く感じる範囲になると不安感が急激に增 す。一方不快度合と限界評価は, 加速度に対する評価値の增加が直 線関倸に近い。総じて限界評価の方が不快度合より増加率は小さい。

これら 4 つの評価尺度と比較して, 形容詞による表現はまったく 異なる傾向を示す。特にその評価値は高掁動数範囲で卓越して大き くなるが，その境にあたる1.6〜2.5Hzでは他と逆に加速度が大きい ほど評価值が小さくなる範囲もあり，振動数に依存した特徵を表す。 図12ではこれらの評価尺度の大小関倸の違いによる振動の範囲を 2 次元的に示した。これまでの考察からそれぞれの評価尺度の特性 は表 3 のように緘められるが，図12の領域はこの特性と対応した特 徴を表していることがわかる。

特徴的な形容詞による表現を別個にとらえてみると，振動数が高 い範囲ほど形容詞による表現の評価が卓越して大きい。それ以外の 評価では, 高振動数範囲では不快度合が大きい振動が多い。高振動 数の振動は物理的な変位も小さく, 振動の物理的な性質の評価は小 さいが，好悪の評価や不快感など主観的な判断を含む程度が強い評 価は跾しい方向に傾く傾向にある。

振動数がより低い掁動に対しては，63gal程度までの籁囲では主 観的な判断よりも振動の物理的な性質の評価が厳しい傾向にある。 一方63galを越える範囲では不快感もかなり大きいが，限界評価は 小さく許容限界はより厳しい評価であることがわかる。

また不安感は63gal以下のほとんどの範囲でもっとも小さい。不

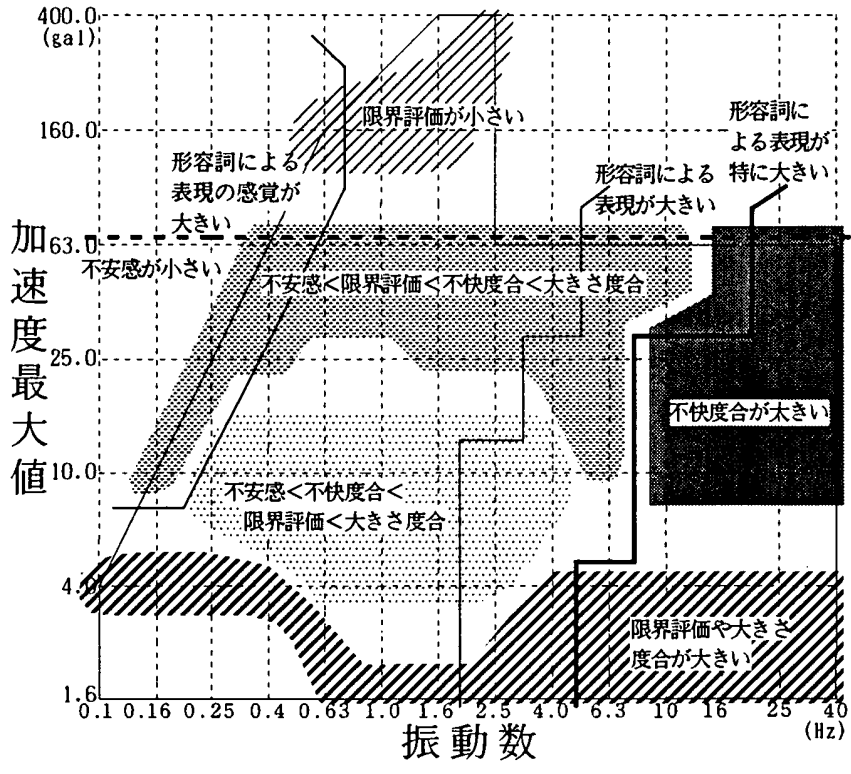

图12 各評伍尺度の関係と物理成分との対麻

\section{表3 各評而尺度の特性}

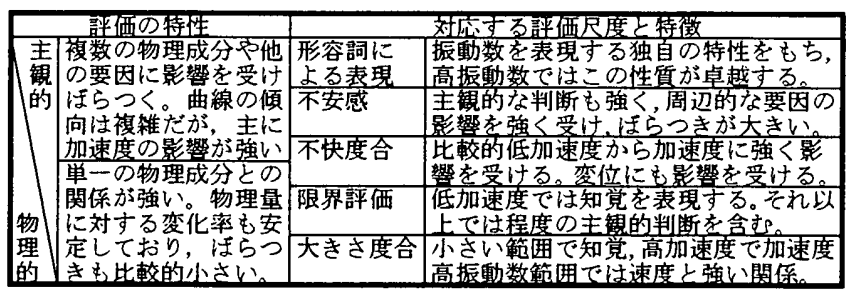

安感は主観的な判断を強く含み，ばらつきが大きいことも含め，よ り鈍い評価であることがわかる。すなわち日常環境で居住者が振動 による不安を訴えた場合かなりの大きさの振動が発生しており，感 覚的な評価も厳しいレベルにあることがわかる。既往のアンケート 調査による摇れに関する居住者の満足度合の意識構造 ${ }^{13}$ からも，不 安は摇れに関する不満につながることが予測できる。

一方摇れを小さいと感じたり，ほとんど感じない場合は不満につ ながることは少ない ${ }^{13)}$ 。知覚闌と関係する加速度が小さい範囲では， 感じる程度の判断や大きさの評価など物理的な評価が若干高く, 他 の主観的な判断の強い評価はそれ以下となっており，摇れに関する 不満も小さいと考えられる。

既往のアンケート調査 ${ }^{13)}$ にみるように摇れに関する不满を構成す る要因は居住者によってさまざまであり，知識や経験など周辺的な 要因の影響も大きい。一方で不安や不快を感じるだけでなく，強い 摇れや大きい摇れなど摇れの物理的な性質の評価が厳しい場合にも 不満を生む要因となることがあるため，実環境における評価につな げる上でも水平振動感覚に対するさまざまな評価の特性を明らかに 寸ることが求められる。

\section{6. おわりに}

本論文では低層から高層建物までを想定した広い振動数範囲の水 平振動を対象に，居住性評価の規範となる感覚に着目した。知賞を はじめとする評価尺度を相互に比較することで，それぞれの特性を 明らかにした。本論文により得られた知見を以下に継める。 
1. $4 \mathrm{gaI}$ 程度以下の筑囲では, 水平振勁感党は知覚と対応して評佂 される。それ以上の加速度筑囲では評価尺度ごとに異なる物理成 分に依存して評価される。各評価尺度は主観的な判断が強く含ま れるものと，振鲌の物理的性質を評価する傾向が強いものに分け られる。振動の知覚や感じた大きさなど振動の物理的な性質を評 価寸る程度が強いほど曲線の傾向は安定し, 単一の物理成分との 明確な対応関倸がある。一方不快感や不安感などの主観的な評価 には加速度が大きく影響するが，複数の物理成分との関㐿から評 価されたり，物理成分以外の要因からも影響を受けや寸いため， ばらつきが大きい傾向にある。また形容詞による表現は振勁数に 対忍した振動の性蜇を表琴する独自の特性をもち, 特に高振動数 の振動が振動数によって評価される特徴がある。

2. 水平振動感觉の評価尺度は共通して2.5Hz付近で曲線の傾きが逆 になり，この振勁数を境に低振動数と高振勁数で評価特性が異な ることがわかった。低振動数筑囲では評価值は振動の物理量の変 動に对して安定した段階的な変動を示し, 被験者によるばらつき も少ない。一方高振動数筑囲では振動数が高いという形容詞の表 兒が卓越する。それ以外は個々の被験者によるばらつきが大きい ことが特徴的であり，各評価尺度が依存する物理成分も加速度， 速度，変位とさまざまであり複雑な特性を示す。

3. 各評価尺度の相互比皎から, その特徴に基づいて振動数筑囲を 4 つに区切ることができた。0.4〜2.5Hz付近の筑囲で各評価尺度の 閵倸が安定し，それ以上の振動数筑囲では形容詞による表現の評 価がきわめて厳しく，各評価尺度のばらつきは大きくなる特徵が ある。これらの大小関保は各評価尺度の特性と対応して変動して おり，知党閣とかかわる低加速度の筑囲では主観的な評価は小さ く，不满の要因も少ないことが予想できる。一方不安感が增す高 加速度の筑囲や不快感が大きい振動数が高い筑囲などでは，それ を要因とした不渵が生じることも考えられ，これらの評価尺度の 特性を考慮した評価が必要となる。

本実験の実施, データ解析にあたっては, 当時卒論生斉藤亜樹子
（現北陸ミサワホーム）, 秋山泉（現東京都庁）の雨氏にご協力咸 いた。感謝の意を表する。また実験にご参加裁いた多くの方々に哚 謝する次第である。

引用立裙

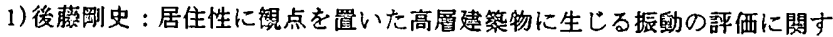

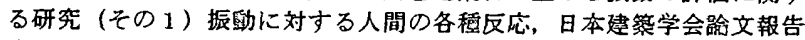
樂, 第237号, 昭和50年11月, pp. 109 1 19.

2）日本建築学会：建筑物に扰ける振動に対する居住性能評価指針，第 1 版、 1990年 4 月.

3）大筑民夫, 田村幸雄, 中田信治, 内藤俊一, 相山伸一：道路交通振镹に

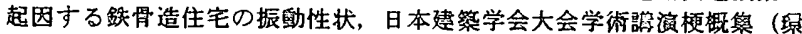
境工学)，pp. 1885 1886，1994年9月.

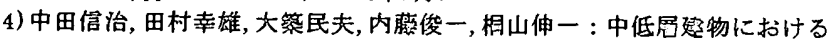

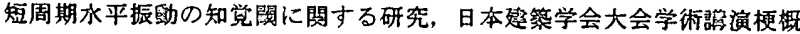
鼻（珢境工学），pp. 1899〜1900，1994年9月.

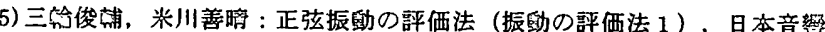
学会誌, 27 巻 1 号, pp. 11 20, 1971年.

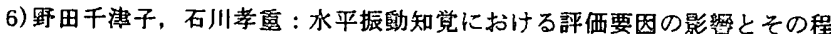
度一その 1 知党瑈に関する既往研究レビューー; 一その 2 知觉限界

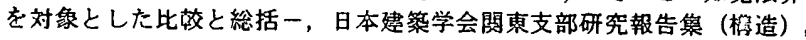
pp. 5 12，1995年度.

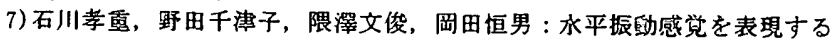
形容詞・用語がもつ意哧, 日本超筑学会計画系踰文報告魚, 第455号, pp 9〜16，1994年1月.

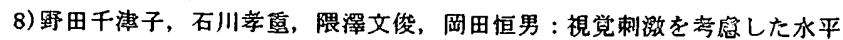

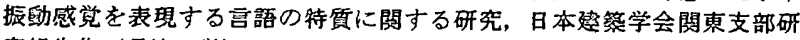

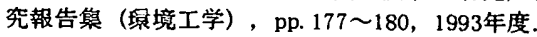

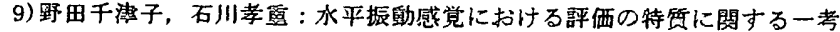
察一個人プロフィルの対応にみる評価尺度の位置つけ一, 日本起築学会 関東支部研究報告鼻（懪境工学），pp.13～16，1994年度.

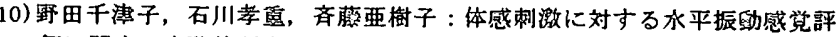

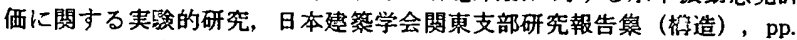
5 8，1996年度。

11）田中良久: 心理学的測定法 第 2 版, 東京大学出版会, 初版, 1985年 5 月10日.

12) 大山正, 池田央, 武藤真介：心理測定 - 統叶法, 有斐閣, 初版, 昭和 46 年9月30日.

13)一力ゆう, 石川葛, 野田千津子：高層住宅の居住性をふまえた摇れ感

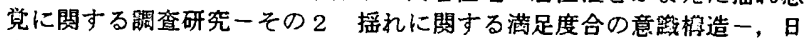

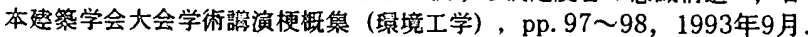

（1997年 7 月 10 日原稿受理，1997年11月14日採用決定） 